J. Clin. Chem. Clin. Biochem.

Vol. 25,1987 , pp. $837-843$

(C) 1987 Walter de Gruyter \& Co.

Berlin - New York

\title{
Macro Lipase - A New Member of the Family of Immunoglobulin-Linked Enzymes
}

\author{
By W. Stein, J. Bohner and M. Bahlinger \\ Abteilung für Innere Medizin 4 (Direktor Prof. Dr. M. Eggstein), Medizinische Universitätsklinik Tübingen
}

(Received February 16/September 1, 1987)

Dedicated to Professor Dr. M. Eggstein on occasion of his 60 th birthday

Summary: This first report describes a variant form of lipase in the serum of a woman suffering from a malignant non-Hodgkin lymphoma. Activity measurements of serum lipase and amylase showed persistently elevated activities of lipase with simultaneously normal activities of amylase. Results of exclusion chromatography and immunological investigations clearly demonstrate that the atypical time-course of lipase activity is not due to injury of the pancreas or alterations of the patient's lipase, but rather due to the presence of lipasebinding autoantibodies, resulting in the formation of immune complexes with high molecular mass $\left(M_{\mathrm{r}}>200000\right)$ between lipase and immunoglobulin $\mathrm{G}$ lambda. A clinical significance, if any, of this macro lipase has yet to be determined.

\section{Introduction}

Determination of the activity of lipase (triacylglycerolacylhydrolase, EC 3.1.1.3) is commonly performed in sera of patients with possible pancreatitis, and it is also used to advantage to document the course of acute and recurrent pancreatitis $(1,2)$. National and international recommendations for the standardisation of the analytical and the diagnostic procedures for this enzyme are still lacking. We, as well as others, therefore usually determine lipase and amylase $(1,4-$ $\alpha$ - $D$-glucan glucanohydrolase, EC 3.2.1.1) activities in parallel in order to combine the technical reliability of the recently developed methods for total activity of amylase $(3-8)$ with the organ specificity of a lipase determination $(9-14)$.

In the serum of a female patient suffering from a nonHodgkin lymphoma we observed significantly elevated lipase activities (up to 7 times the upper reference limit) for several weeks. Usually the finding of such an increased serum lipase activity is regarded as a specific indicator of acute injury to the pancreas. However, in this case the reason for the elevated lipase activities was unclear, because total amylase activities always remained normal. Several possible mechanisms can explain such unusual enzyme patterns:
1. Inhibition of amylase activity or release.

2. Occurrence of an unusual lipase isoenzyme.

3. Decrease of the rate of elimination of lipase activity.

4. Persistence of lipase in blood after complexation of lipase with a plasma protein and formation of macro lipase.

Here we report a case of macro lipase, which, to our knowledge is the first description of serum lipase linked to immunoglobulin $\mathrm{G}$ lambda.

\section{Materials and Methods}

Samples

Serum specimens were either analysed on the same day they were obtained, stored at $4{ }^{\circ} \mathrm{C}$ for not longer than $24 \mathrm{~h}$, or were kept at $-20^{\circ} \mathrm{C}$ without any additives until the assay.

\section{Enzyme assays}

We measured lipase catalytic activity with a turbidimetric method (cat. Nos. 159697 and 262358, Boehringer Mannheim, Mannheim, F.R.G.) and the recently introduced lipase-UV method (code No. 999-00508, Wako Chemicals GmbH, NeuB, F. R.G.) at $25^{\circ} \mathrm{C}$ and $37^{\circ} \mathrm{C}$ according to the manufacturers' instructions. The activities were determined using either a spectrometer (Model M 1101) or an ACP 5040 instrument (both 
from Eppendorf Gerätebau, Hamburg, F. R. G.). We also performed mass determinations of lipase with an immunoassay (Enzygnost-Lipase, cat. No. OUEK 10/11, lot. No. 17862, Behringwerke, Marburg, F. R.G.) according to the manufacturer's instructions. Amylase activity was determined at $25^{\circ} \mathrm{C}$ using Testomar-Amylase (cat. No. ØSVV 10, Behringwerke). Determinations of other serum enzyme activities were performed according to the recommendations of the Deutsche Gesellschaft für Klinische Chemie (15). Differentiation of serum immunoglobulins was obtained using the Paragon IFE system (Beckman Instruments GmbH, München, F. R. G.).

\section{Exclusion chromatography}

A $26 \times 0.9 \mathrm{~cm}$ column packed with Sephacryl S-300 sf (Pharmacia, Uppsala, Schweden) was used with a mobile phase containing, per liter, $50 \mathrm{mmol}$ of Tris (pH 7.0), $50 \mathrm{mmol}$ of $\mathrm{NaCl}$, and $200 \mathrm{mg}$ of $\mathrm{NaN}_{3}$. The sample volume was $200 \mu \mathrm{l}$, the flow rate about $3 \mathrm{ml} / \mathrm{h}$, and the fraction volume $440 \mu \mathrm{l}$. Post-column lipase activities and concentrations were determined using the enzyme assays described. To increase sensitivity, the sample volume was doubled and the activity was measured at $37^{\circ} \mathrm{C}$.

For determination of the relative molecular masses the column was calibrated as described previously (16); it was also calibrated with a serum containing IgG-linked creatine kinase-BB, of which the molecular mass had been determined by gradient electrophoresis on polyacrylamide gel (16).

\section{Affinity chromatography}

$500 \mu \mathrm{l}$ of serum containing IgG-linked lipase was adsorbed on a column $(3 \times 0.4 \mathrm{~cm})$ packed with Protein A-Sepharose CL4B (Pharmacia) (17). Normal-sized lipase and other serum constituents not bound to the column matrix were eluted with ten $0.5 \mathrm{ml}$ fractions of Tris buffer ( $50 \mathrm{mmol} / \mathrm{l}, \mathrm{pH} \mathrm{8.0)}$ containing, per liter, $50 \mathrm{mmol}$ of $\mathrm{NaCl}$ and $200 \mathrm{mg}$ of $\mathrm{NaN}_{3}$. The IgGbound lipase was detached from Protein A with ten $0.5 \mathrm{ml}$ fractions of $0.5 \mathrm{~mol} / \mathrm{l}$ acetic acid $(\mathrm{pH} 3)$. The fractions eluted from the column were neutralized with $500 \mu$ l of Tris buffer and lipase determined as described above.

\section{Purification of IgG}

After heat inactivation of lipase activity $\left(2.5 \mathrm{~h}, 50^{\circ} \mathrm{C}\right)$, immunoglobulin $G$ (subclasses $1,2,4$ ) was purified from $4 \mathrm{ml}$ serum by affinity chromatography on Protein A-Sepharose CL-4B as described earlier (18). Proteins not retained by the column were collected, neutralized and concentrated in the same way (solution A).

\section{Recombination of macro lipase in vitro}

The purified IgG solution was either incubated with a serum of a patient with acute pancreatitis or with lipase prepared from human pancreas fluid for $1 \mathrm{~h}$ at $4^{\circ} \mathrm{C}$ before exclusion chromatography.

\section{Immunological techniques}

The serum containing macro lipase and controls were reacted with specific antisera against human immunoglobulins. These included anti-IgA, anti-IgM, anti-IgG (all from Dako, København, Denmark), anti-kappa and anti-lambda (Behringwerke). To constant amounts of lipase activity $(25 \mu \mathrm{l})$ we added increasing volumes of the respective antisera, imidazole buffer $\left(100 \mathrm{mmol} / \mathrm{l}, \mathrm{pH} 6.9\right.$ at $\left.25^{\circ} \mathrm{C}\right)$ and polyethylene glycol 6000 solution to give a final volume of $200 \mu$ l. The final concentration of polyethylene glycol 6000 was $30 \mathrm{~g} / \mathrm{l}$. Before determination of lipase activity in the supernatants the tubes were incubated overnight at $4{ }^{\circ} \mathrm{C}$. To increase sensitivity and precision, the sample volume was increased as indicated.

\section{Investigation of catalytic activity}

To assess the thermostability of lipase in the samples we determined heat inactivation at $50^{\circ} \mathrm{C}$ and at three different $\mathrm{pH}$ values $(6.5,7.4,8.3)$. Possible inhibition of the activity of lipase by the lipase-binding antibodies was determined by titration of human lipase with the IgG preparation of serum Lut. To 100 $\mu \mathrm{l}$ of a serum with elevated normal-sized lipase (catalytic concentration ca. $700 \mathrm{U} / 1$ at $25^{\circ} \mathrm{C}$ ) we added increasing amounts of lipase-binding IgG and supplemented the mixture with solution $A$ to give a final volume of $200 \mu l$ in each tube. The tubes were incubated for $36 \mathrm{~h}$ at $4{ }^{\circ} \mathrm{C}$, followed by determination of lipase activity. Apparent energies of activation of the lipase-catalysed reaction were determined as described previously (19) for creatine kinase isoenzymes and macro creatine kinase.

\section{Case Report}

The sera studied were obtained from patient Lut., a woman aged 45 years with a non-Hodgkin lymphoma classified as low malignant. During ber stay, therapy was initiated according to the ALL protocol (cf. legend to fig. 1). During this therapy, growth of the tumour was progredient which e.g. could be documented by increasing amounts of $\gamma$-globulins (fraction 0.25 , total protein $63 \mathrm{~g} / \mathrm{l}$ ) and the proof of bands of apparently monoclonal origin. Additionally she developed increasing activities of serum lipase without any clinical signs or complaints and without characteristic radiographic and ultrasonographic findings suspicious of pancreatitis or other affections of this organ (fig. 1), and without a concomitant elevation of her serum amylase activity. As this type of therapy proved to be unsuccessful, another scheme (VIM/BLEO) (cf. legend to fig. 1) was chosen which was more successful, and in the course of which lipase activity and relative amount of immunoglobulins normalized ( $\gamma$-globulin fraction 0.19 , total protein $62 \mathrm{~g} / \mathrm{l}$ ).

The results presented in our paper were obtained from experiments with samples taken at November 6, 10, and 12 (fig. 1), when macro lipase activity was highest.

\section{Results}

The persistently raised activity of lipase without concomitant increase of amylase activity was investigated and is explained by the presence of a macro lipase.

\section{Molecular size}

Figure 2 shows the typical patterns obtained by size exclusion chromatography on the Sephacryl S-300 sf column. In contrast to normal-sized lipase present in the serum of a patient suffering of acute pancreatitis, which elutes with maximum activity in fraction 33 , under the same conditions the lipase activity of serum Lut. is eluted earlier with maximum activity in fractions $26 / 27$. This distinctly higher relative molecular mass of about 250000 is due to complexation of the lipase with IgG as shown below. The increase of the relative molecular mass is not due to complexation with colipase (results not shown). 


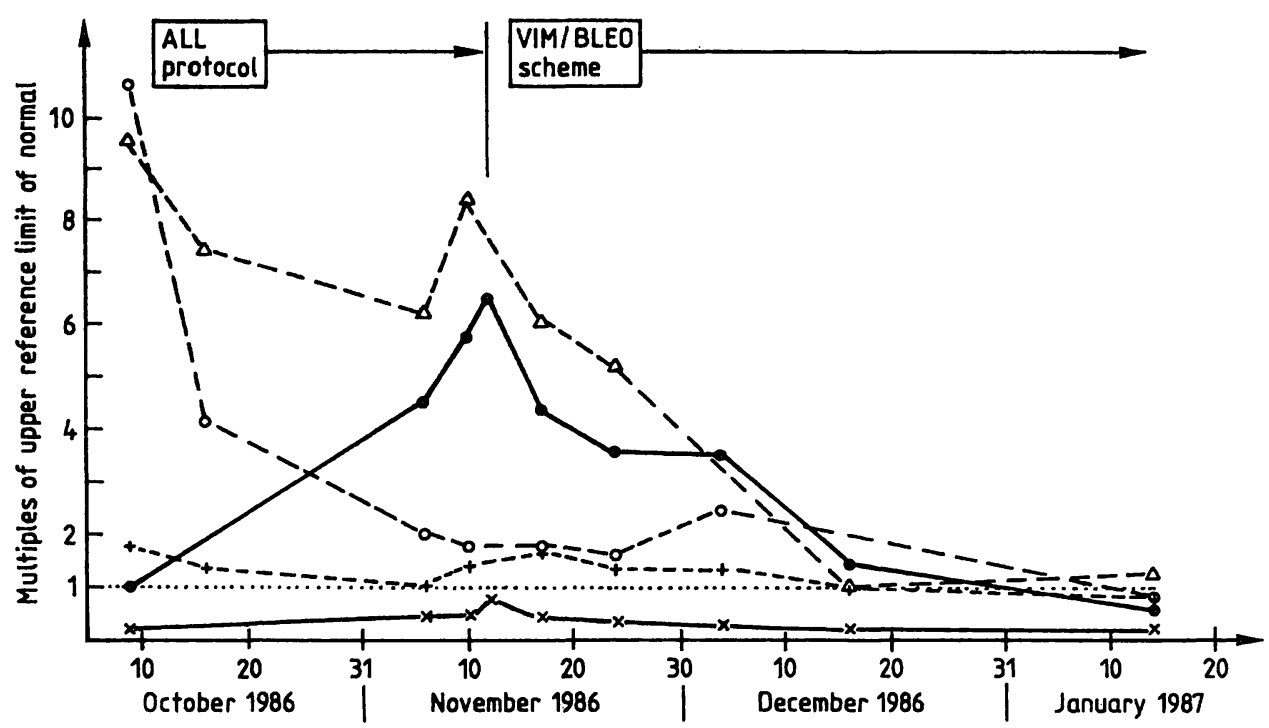

Fig. 1. Time-course of enzyme activities.

ALL protocol: therapy with vincristine, daunorubicine, asparaginase, prednisolone.

VIM/BLEO scheme: therapy with etoposide, methotrexate, ifosfamide, bleomycine.

$0-0$ : lipase activity, $x-x$ :amylase activity, $0-0$ : lactate dehydrogenase activity, $\Delta-\Delta: \gamma$-glutamyltransferase activity, +-+ : alanine aminotransferase activity.

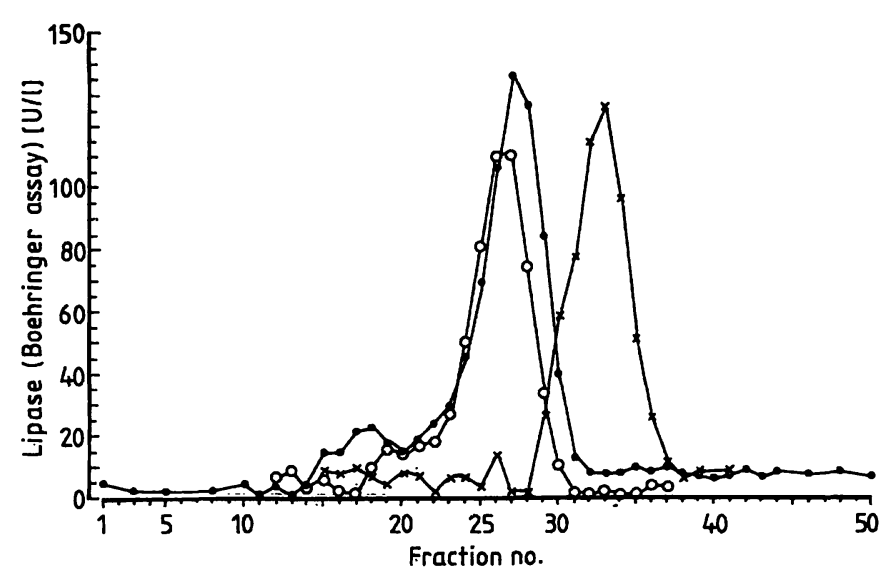

Fig. 2. Exclusion-chromatographic pattern of serum lipases. Conditions of run: see text.

$0-0$ : serum of patient Lut. (macro lipase).

$x-x$ : serum of a patient with pancreatitis (normal-sized lipase).

O- $\mathrm{O}$ : mixture of equal amounts of both sera.

\section{Evidence of lipașe-binding immunoglobulins}

Macro lipase was separated from the serum by affinity chromatography on Protein A-Sepharose CL-4B. As already described $(17,18,20)$, not only free immunoglobulin $G$ but also enzyme-linked immunoglobulin $G$ is quantitatively fixed by Protein A (fig. 3), whereas normal-sized lipase passes the column without retention. Binding occurs via the Fc fragment of the immunoglobulins, leaving the antigen-binding sites unaffected. The bound macro lipase afterwards was detached by decreasing the $\mathrm{pH}$ of the mobile phase to about 3.0.

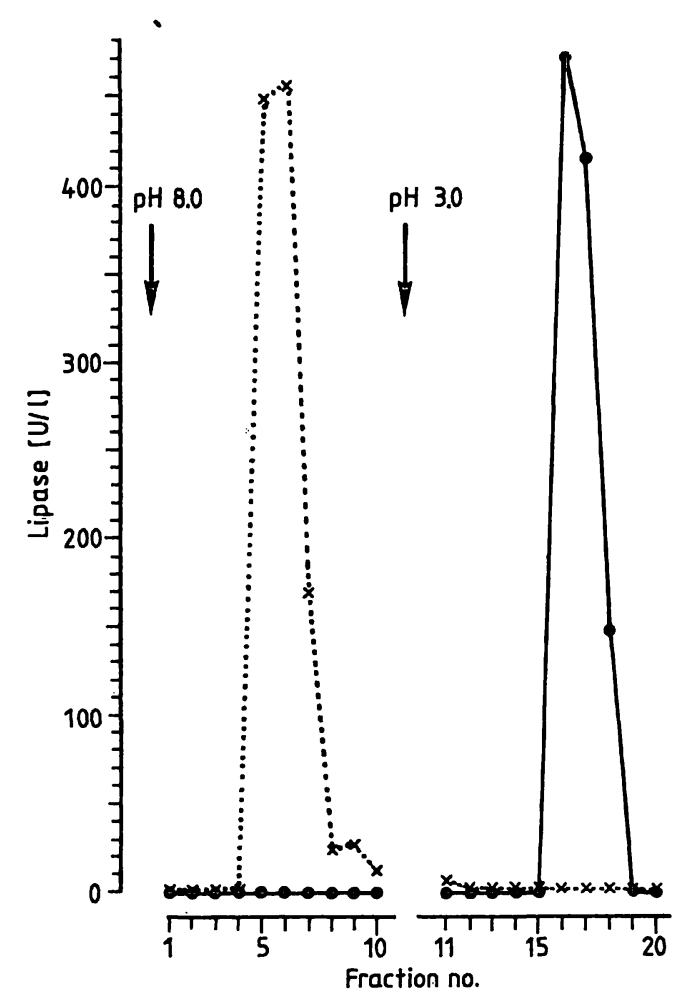

Fig. 3. Affinity chromatography on Protein A-Sepharose CL4B. Conditions of run: see text; fraction of $500 \mu \mathrm{l}$ were collected.

x...x: normal-sized lipase.

๑-0: IgG-linked lipase.

Lipase-free immunoglobulins of serum Lut. prepared after heat inactivation by affinity chromatography, recombined not only with autologous but also with homologous lipase to form macro lipase. Both methods gave the same information when used for the 
analysis of the lipase activity of chromatography fractions (fig. 4). It was therefore possible to document the re-formation of macro lipase and to exclude possible artifacts. Correlation between both activity determinations ( $\mathrm{Bö}=$ Boehringer, $\mathrm{Wa}=$ Wako) was: $\mathrm{y}(\mathrm{Bö})=1.76 \mathrm{x}(\mathrm{Wa})-8.7, \mathrm{r}=0.98, \mathrm{~N}=20$.

The binding immunoglobulins are present in the serum in excess of the lipase. Figure 2 documents the results obtained after mixing equal amounts of serum Lut. with a serum of a patient with pancreatitis (lipase catalytic concentration about $1000 \mathrm{U} / 1$ at $25^{\circ} \mathrm{C}$ ). The normal-sized lipase is quantitatively converted into macro lipase and elutes with maximum activity in fractions $26 / 27$ after exclusion chromatography.

For amylase activity we obtained the results expected (not shown), and did not detect any significant inhibition.
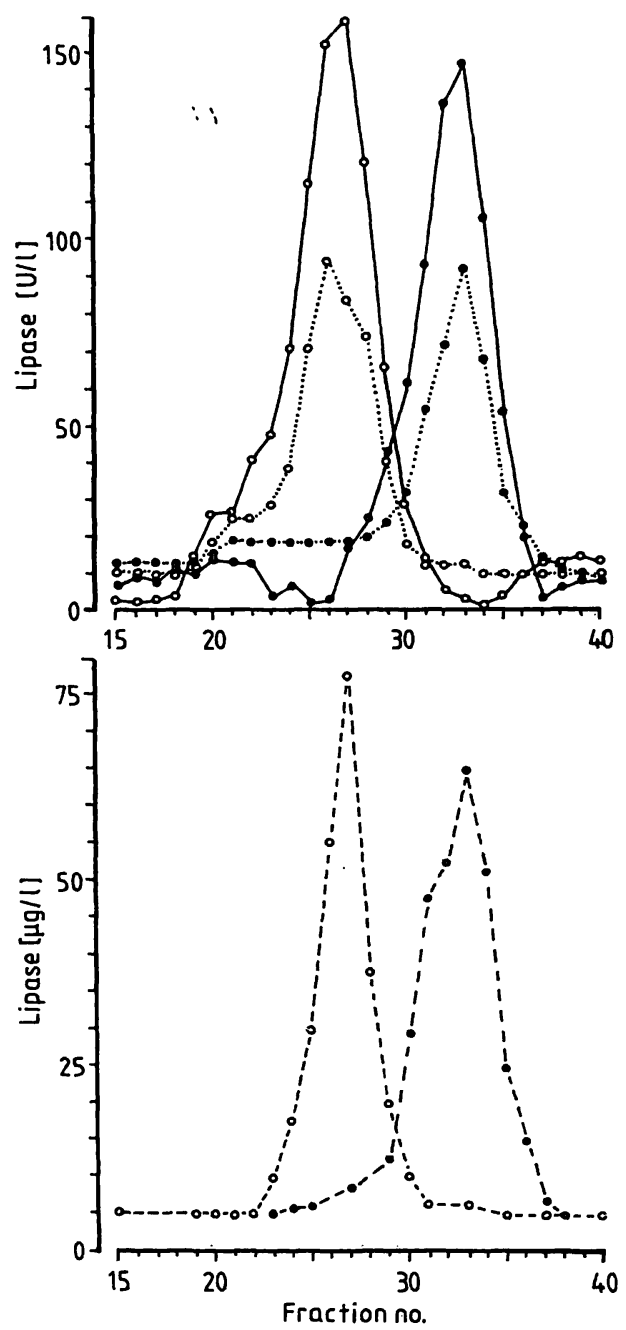

Fig. 4. Complexation of lipase by specific immunoglobulins. Exclusion-chromatographic pattern.

Conditions of run: see text.

Incubation of normal-sized pancreas lipase (o) with IgG prepared from serum Lut. resulted in re-formation of macro lipase (0). Lipase activities were determined by the turbidimetric method (Boehringer) $(-)$, by the UV assay (Wako) ( ..), and by the immunological procedure (Behringwerke) (---).

\section{Immunological investigations}

Reacting the serum with antisera directed against the $G$ class of heavy and the lambda class of light chains of human immunoglobulins precipitated significant amounts of enzyme activity in the quantitative precipitation test. Partial precipitation was achieved by anti-kappa antibodies (fig. 5). There was no decrease in lipase activity in the supernatant when the serum $\operatorname{IgM}$ or IgA were precipitated with specific antisera.

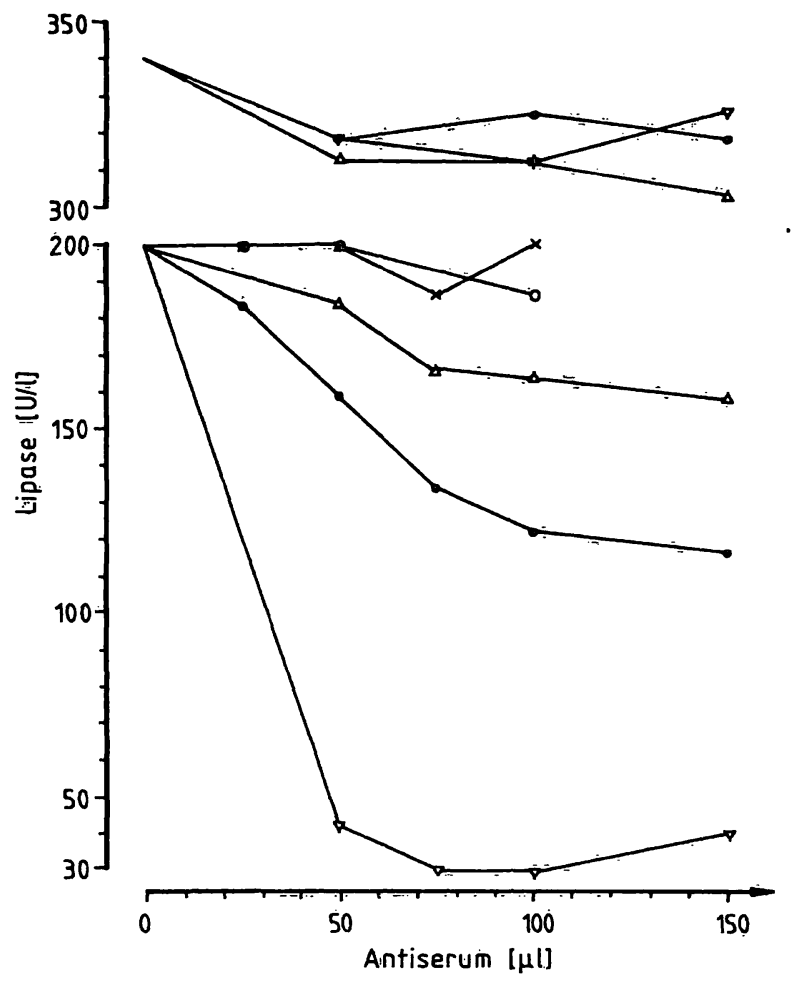

Fig. 5. Precipitation test.

y-axis: residual lipase activity of the supernatants after precipitation of the respective immunoglobulins.

Upper panel: serum of a patient with acute pancreatitis. Lower panel: serum Lut.

Types of antisera added: ๑: anti-IgG, ०: anti-IgA, $x$ : anti-IgM, $\triangle$ : anti-kappa, $\nabla$ : anti-lambda.

The commercially available antibodies directed against lipase detected the lipase moiety of the macro lipase not only in the serum samples but also in the chromatography fractions (fig. 4).

\section{Investigations concerning catalytic activity}

Specific activity $(\mathrm{U} / \mathrm{mg})$ at $25^{\circ} \mathrm{C}$ was calculated by dividing the results of the activity measurements (U/l) by the results of the immunoassay (mg/l). We could not substantiate characteristic differences between normal lipase $(2400 \mathrm{U} / \mathrm{mg}$ ) and macro lipase (2500 $\mathrm{U} / \mathrm{mg}$ ), regardless of whether we assayed whole serum or the chromatography fractions of figure 4. 
Titration of normal-sized lipase with lipase-binding immunoglobulin $G$ prepared from serum Lut., resulted in an inhibition of enzyme activity. The increasing amounts of the autoantibody converted normalsized lipase into the macro form and simultaneously inhibited enzyme activity by about $30 \%$.

Furthermore we determined the decrease in enzyme activity of macro lipase caused by thermal inactivation and shifts in $\mathrm{pH}$ during storage at $50^{\circ} \mathrm{C}$. There was no difference between normal-sized and Ig-linked lipase; generally inactivation increased with increasing $\mathrm{pH}$ values of the matrix (results not shown).

Dependence of enzyme activity on temperature was determined with both tests. At higher temperatures the Arrhenius plots deviate from a linear relationship (fig. 6). We therefore only calculated apparent energies of activation for the temperature interval $25-34{ }^{\circ} \mathrm{C}$. The activation energies compare well with recently published results (22), which were obtained using different assays. Determinations of the energies of activation by the assays used in our study (tab. 1) do not allow differentiation of the two types of lipase.
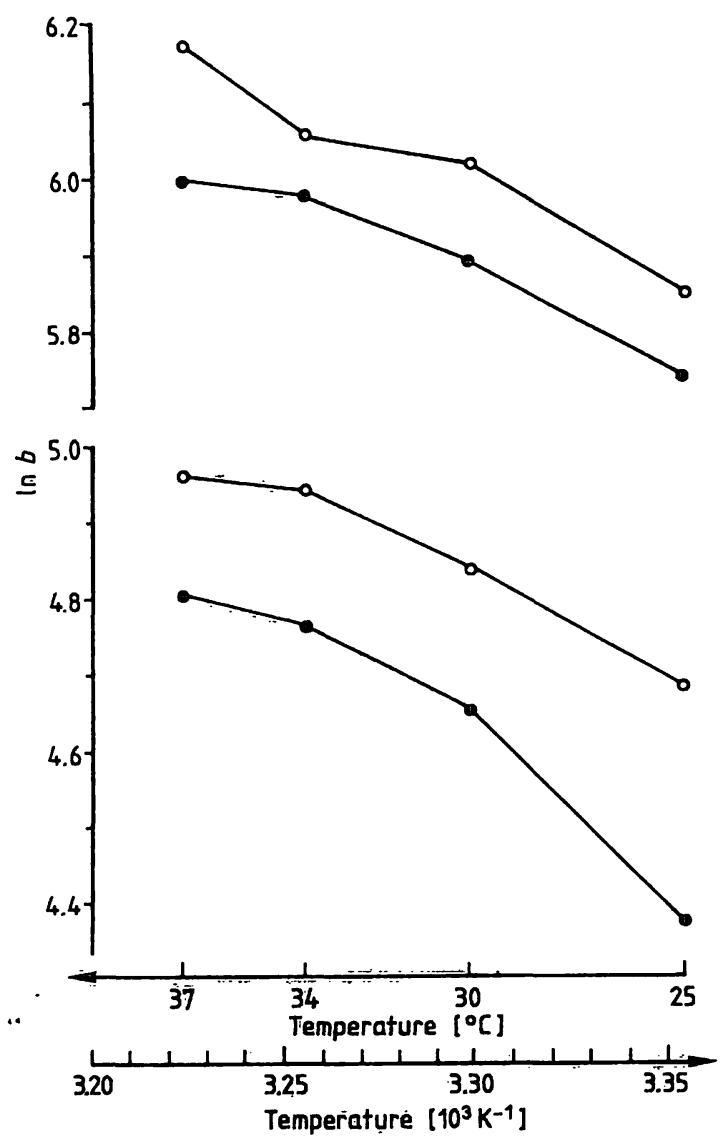

Fig. 6. Enzyme activity as a function of temperature. Catalytic concentration $b[\mathrm{U} / \mathrm{d}]$ plotted as natural logarithm. Upper panel: activity determined by the turbidimetric assay (Boehringer). •

Lower panel: activity determined by the UV assay (Wako).

- ๑: macro lipase, o- o: normal-sized lipase.
Tab. 1. Activation energies $(\mathrm{kJ} / \mathrm{mol})$. Average, apparent values determined for a temperature interval from 25 to $34^{\circ} \mathrm{C}$.

\begin{tabular}{lll}
\hline $\begin{array}{l}\text { Method of activity } \\
\text { determination }\end{array}$ & $\begin{array}{l}\text { Macro } \\
\text { lipase }\end{array}$ & $\begin{array}{l}\text { Normal-size } \\
\text { lipase }\end{array}$ \\
\hline $\begin{array}{l}\text { Turbidimetric assay } \\
\text { (Boehringer) }\end{array}$ & 23 & 20 \\
$\begin{array}{l}\text { UV assay } \\
\text { (Wako) }\end{array}$ & 26 & 21 \\
\hline
\end{tabular}

\section{Discussion}

Our documentation of lipase-IgG complexes (macro lipase) in the serum of a patient suffering from a malignant lymphoma is based on the following results:

1. During exclusion chromatography the vast majority of the patient's lipase eluted a little later than IgGlinked creatine kinase-BB under the same conditions, its elution volume corresponding to a relative molecular mass of about 250000 . Such relative molecular masses are expected for complexes with a $2: 1$ molar ratio between lipase and IgG, but not for uncomplexed lipase (molecular mass 48000 ) (for references see 1.c. (1)). Complexes of the same $2: 1$ molar ratio have recently been reported for IgG(kappa)-linked creatine kinase-BB, IgG(lambda)-linked creatine kinase-BB (18) and IgA(kappa)-linked lactate dehydrogenase isoenzyme 5 (23).

2. The nature of the immunoglobulins binding to lipase was elucidated by immunological methods: the heavy chains belong to the gamma, the light chains to the lambda class.

3. The Fc regions of the binding IgG are free, because the macromolecular complexes are quantitatively fixed by Protein A. This in turn suggests that lipase is attached to the Fab regions of IgG and that the complexes are immune complexes formed by an antibody-antigen reaction.

4. The binding is reversible: thermal inactivation destroyed all serum lipase activity. After purification and preparation of the IgG it easily combined with exogenous lipase to form macro lipase again. This observation furthermore indicates that the patient's lipase is apparently not modified in a way that would cause complex formation. Binding of lipase to the IgG is accompanied by a slight, probably steric, inhibition of catalytic activity. There was no evidence for changes in thermal stability, in stability to shifts of $\mathrm{pH}$, in catalytic efficiency expressed as activation energy, or in specific activity, which was recently reported to range from $1000-3000 \mathrm{U} / \mathrm{mg}\left(25^{\circ} \mathrm{C}\right)$ in human serum (24). It is not known whether this wide 
range is due to intra-individual variations, due to analytical imprecisions or both. The inhibition of lipase activity after complexing with $\mathrm{IgG}$ apparently is accompanied by a concomitant alteration of the mass determination applied; because we could not substantiate differences in the specific activities $(\mathrm{U} / \mathrm{mg})$ of lipase and macro lipase.

5. The antibodies are present in the patient's serum in excess of the endogenous lipase, therefore it is very unlikely that macro lipase is a result of a variant gene.

Our results indicate that a specific antigen-antibody reaction is responsible for this postsynthetic modification of lipase and for the observed existence of macro lipase, and that macro lipase therefore may be regarded as a new member of the family of the Iglinked enzymes $(25-33)$ of which the first, macro amylase, was described in 1964.

The presence of macro lipase in this serum may be explained by the production of a specific immunoglobulin $G$ with high affinity for lipase. This points to association s between autoimmune phenomena, macro lipase and the non-Hodgkin lymphoma of the patient. In support of this we observed a close relationship between the clinical state of disease, success of therapy, relative amount of $\gamma$-globulins, and activity of macro lipase. During unsuccessful therapy and tumour growth, macro lipase activity increased (fig. 1); during successful therapy, the activity of macro lipase decreased to values below the upper reference limit for serum lipase activity. In the latter case, chromatography showed a very small macro lipase peak, and the lipase binding capacity of the serum was very low. We further conclude that it is unlikely that affections of the pancreas are responsible for the pres- ence of macro lipase in our patient's serum, but that the amount of macro lipase observed is the result of the concentration and the affinity of the circulating antibodies and the amount of lipase released from the pancreas. A physiological and/or pathobiochemical function of this type of antibody production against endogenous proteins like lipase is still obscure and hardly understood.

In routine and emergency laboratories, the determination of activities of serum lipase and amylase are well established in the evaluation of patients presenting with possible pancratitis. On the one hand, the existence of isoenzymes and macro amylase decreases the specificity of amylase and may lead to diagnostic confusion, so that hyperamylasaemia alone cannot be used to diagnose pancreatitis. On the other hand, significantly increased serum lipase values are regarded to be very specific indicators for acute pancreatitis or affections of organs close to the pancreas (2), in spite of the evidence of multiple forms of serum lipase $(1,34-36)$. The interesting pattern, however, first observed in our patient, showed that serum lipase activity may well be significantly elevated in some cases where amylase activity remains normal and there is no clinical evidence of abdominal distress or acute inflammation of the pancreas. Differential diagnosis of abdominal diseases may be complicated by the presence of macro lipase, which, like macro amylase, may be responsible for falsely elevated serum activities in a minority of cases.

\section{Acknowledgement}

Supported by Deutsche Forschungsgemeinschaft. Reagents were kindly provided by Wako Chemicals $\mathrm{GmbH}$.

\section{References}

1. Lorentz, K. \& Weiß, T. (1981) Medizin. Lab. 34, 272-277.

2. Lott, J. A., Patel, S. T., Sawhney, A. K., Kazmierczak, S. C. \& Love, J. E. (1986) Clin. Chem. 32, 1290-1302.

3. Wallenfels, K., Földi, P., Niermann, H., Bender, H. \& Linder, D. (1978) Carbohydrate Res. 61, 359-368.

4. Rauscher, E., Bülow, v. S., Neumann, U. \& Schaich, E. (1981) Ber. Österr. Ges. Klin. Chem. 4, 150.

5. Henkel, E., Morich, S. \& Henkel, R. (1984) J. Clin. Chem. Clin. Biochem. 22, 489-495.

6. Zakowski, J. \& Bruns, D. E. (1985) CRC Critical Reviews $21,282-322$.

7. Rauscher, E., Bülow, v. S., Hägele, E. O., Neumann, U. \& Schaich, E. (1986) Z. Analyt. Chem. 324, 304.

8. Dupuy, G., Hilaire, G. \& Aubry, C. (1987) Clin. Chem. 33, $524-528$.

9. Rick, W. (1969) Z. Klin. Chem. Klin. Biochem. 7, 530539.

10. Tietz, N. W. \& Repique, E. V. (1973) Clin. Chem. 19, $1268-$ 1275.

11. Ziegenhorn, J., Neumann, U., Knitsch, K. W. \& Żwez, W. (1979) Clin. Chem. 25, 1067.

12. Junge, W., Leybold, K. \& Kraak, B. (1983). J. Clin. Chem. Clin. Biochem. 21, 445-451.

13. Mauck, J. C., Weaver, M. S. \& Stanton, C. (1984) Clin. Chem. 30, 1058 .

14. Imamura, S. \& Misaki, H. (1984) Selected Topics in Clin. Enzymol. 2, 73.

15. Empfehlungen der Deutschen Gesellschaft für Klinische Chemie (1972) J. Clin. Chem. Clin. Biochem. 10, 182-192. (1977) J. Clin. Chem. Clin. Biochem. 15, 249-254.

16. Stein, W., Bohner, J. \& Bahlinger, M. (1985) Clin. Chem. 31, 1952-1958.

17. Goding, J. W. (1978) J. Immunol. Meth. 20, 241-253.

18. Stein, W., Bohner, J., Krais, J., Müller, M., Steinhart, R. \& Eggstein, M. (1981) J. Clin. Chem. Clin. Biochem. 19, 925-930.

19. Stein, W., Bohner, J., Steinhart, R. \& Eggstein, M. (1982) Clin. Chem. 28, 19-24.

20. Bauer, K., Bayer, P. M., Deutsch, E. \& Gabl, F. (1980) Clin. Chem. 26, 297-300.

21. Arrhenius, S. (1889) Z. Phys. Chem. 4, 226-248. 
22. Rick, W. \& Hockeborn, M. (1984) J. Clin. Chem. Clin. Biochem. 22, 357-370.

23. Weijers, R. N. M., Mulder, J. \& Kruijswijk, H. (1983) Clin. Chem. 29, 272-278.

24. Hoffmann, G. E., Junge, W., Schmidt, D., Weiss, L. \& Hoffmann, S. (1984) Ärztl. Lab. 30, 193-196.

25. Wilding, P., Cooke, W. T. \& Nicholson, G. I. (1964) Ann. Intern. Med. 60, 1053-1059.

26. Ganrot, P. O. (1967) Experientia 23, 593.

27. Kindmark, C. O. (1969) Scand. J. Clin. Lab. Invest. 24, $49-53$.

28. Nagamine, M. \& Ohkuma, S. (1975) Clin. Chim. Acta 65 , $39-46$.

29. Konttinen, A., Murros, J., Ojala, K., Salaspuro, M., Somer, H. \& Räsänen, J. (1978) Clin. Chim. Acta 84, 145-147.
30. Kajita, Y., Majima, T., Yoshimura, M., Hachiya, T., Miyazaki, T., Ijichi, H. \& Ochi, Y. (1978) Clin. Chim. Acta $89,485-492$.

31. Urdal, P. \& Landaas, S. (1979) Clin. Chem. 2S, 461-465.

32. Bohner, J., Stein, W., Kuhlmann, E. \& Eggstein, M. (1979) Clin. Chim. Acta 97, 83-88.

33. Nakayama, T., Sakugi, F., Tsukado, T. \& Kitamura, M. (1983) IV. Int. Congress on Clin. Enzymology, Arlington, VA, USA.

34. Vogel, W. C. \& Zieve, L. (1963) Clin. Chem. 9, 168-181.

35. Kapaun, W., Meier-Cabell, E., Müller-Wieland, K. \& Berndt, W. (1976) Verh. Deutsch. Ges. Inn. Med. 82, 963965.

36. Arzoglu, P. L., Lessinger, J. M. \& Férard, G. (1986) Clin. Chem. 32, 50-52.
Privatdozent

Dr. Dr. Wolfgang Stein

Medizinische Universitätsklinik

Abteilung 4

D-7400 Tübingen 
